\title{
Anthropogenic Impact on Species Diversity and Distribution of Birds from Coastal Region of Panvel, Navi Mumbai, India
}

\author{
Pawar Prabhakar R.*, Rokade Anil G., Supnekar Santosh P., Meshram Leena N. and Pawar \\ Namdeo B.
}

Mahatma Phule Arts, Science and Commerce College, Panvel, Raigad, Navi Mumbai - 410206, India

${ }^{*}$ Corresponding Author

Received: $7^{\text {th }}$ June, 2020

Accepted: 2nd July, 2020

Published online: $6^{\text {th }}$ July, 2020

https://doi.org/10.33745/ijzi.2020.v06i02.005

\begin{abstract}
Present study was conducted to assess the impact of over-exploitation of natural resources and deforestation on diversity and distribution of avian species from Panvel, Navi Mumbai. Birds were surveyed during dawn and dusk hours by using point count method in different localities for one year (from June 2019 to May 2020). Varied diversity of birds with 102 species representing 16 orders, 48 families and 84 genera were observed. Number of species of birds distributed in each family reveals that 45 species belongs to family Passeriformes, 12 species to Charadriiformes, 10 species to Pelecaniformes, 8 species to Accipitriformes, 7 species to Coraciiformes, 3 species each to Columbiformes, Piciformes and Strigiformes; 2 species each to Anseriformes, Bucerotiformes and Gruiformes and 1 species each to Cuculiformes, Galliformes, Phoenicopteriformes, Psittaciformes and Suliformes. At present, ecological conditions in area adjoining Panvel, Navi Mumbai supports moderate avian density but overexploitation of natural resources and deforestation in Panvel region due to ongoing construction of Navi Mumbai International Airport (NMIA) are the key factors affecting the diversity and distribution of avian species. As the bird community react rapidly to anthropogenic impact, restoration of large forest patches and well planned plantation of conservation plants is recommended. Since no earlier reports are available, data presented here can be taken as a baseline data in knowing the status of birds of Panvel, Navi Mumbai and effect of industrial development on it.
\end{abstract}

Keywords: Avifauna, Human activity, Navi Mumbai International Airport, Navi Mumbai, Panvel, Species diversity

Citation: Pawar Prabhakar R., Rokade Anil G., Supnekar Santosh P., Meshram Leena N. and Pawar Namdeo B.: Anthropogenic impact on species diversity and distribution of birds from coastal region of Panvel, Navi Mumbai, India. Intern. J. Zool. Invest. 6 (2): 260-271, 2020. https://doi.org/10.33745/ijzi.2020.v06i02.005

\section{Introduction}

Biodiversity is widely acknowledged to influence the magnitude and stability of a large array of ecosystem properties, with bio diverse systems thought to be more 
functionally robust. As such, diverse systems may be safer harbors for vulnerable species, resulting in a positive association between biodiversity and the collective vulnerability of species in an assemblage (Weeks et al., 2016).

Asia was considered among most diversity-rich continents, however, increase in human population has adversely affected the diversity of the region as the increasing populations demanded for food and shelter which resulted in agriculture intensification, urbanization, industrialization, and pollution. Population census of all the species in urbanized and peri-urban areas is a prerequisite for conservation planning (Altaf et al., 2018).

Biodiversity might be affected by anthropogenic activity which comprises a collection of human created disturbance events that can have long- and short-term impacts on wildlife by inducing changes in behaviour, physiology and reproduction. Increases in anthropogenic activity decrease the persistence of local populations by compromising habitat suitability, restraining feeding and breeding opportunities and increasing regional extinctions of wildlife species (Sheta et al., 2011).

Urbanisation is a dominant geographical trend and an important component of global change, with unprecedented implications for socio-economic, cultural and environmental characteristics (Pedreros et al., 2018). Degradation and destruction of habitats due to anthropogenic actions are major causes of global biodiversity declines. Understanding inter-specific variation in species responses to human disturbances is important to enable effective conservation decision making (Asefa et al., 2017).
Birds are excellent bio-indicators of the effects of urbanization on ecosystems since they are highly diverse and conspicuous elements of the ecosystems. They are key species of different ecosystems because they are highly distributed, easily visible and evocative to us. Bird species richness is influenced by the urban environment, landscape, floral diversity, degree of anthropogenic disturbances, invasion as well as predation, yet they are major part of urban biodiversity (Maurice et al., 2020).

Birds play many roles in maintaining ecosystems and supporting biodiversity like they are bioindicators of healthy ecosystems, regulate disease vectors, biomass recycling and reduce levels of disposable wastes (Gatesire et al., 2014). They are also important as pollinators, scavengers and biomonitors controlling insects, pests and excellent ecology indicators as well as act as primary and tertiary consumers in the food chain and help in recycling of nutrients (Ratchford et al., 2005; Galgani et al., 2010; Sheta et al., 2011; Joshi and Krishna, 2014; Kadam and Dhar, 2017; Kurve, 2017; Altaf et al., 2018; Maurice et al., 2020).

Dey et al. (2013) reported that India have more than 1300 species of birds and which is over $13 \%$ of the world bird species but, unfortunately India is the third among the countries having the largest number of threatened and rare species followed by Brazil and Indonesia (Rajashekara and Venkatesha, 2015).

Species diversity of birds currently inhabiting any specific area, their distribution records and the levels of threat to the species help in protection efforts. Major threats to birds include illegal hunting, urbanization, 
agriculture intensification, eutrophication, pollution, and livestock grazing (Bhadouria et al., 2012; Dwivedi and Singh, 2017; Altaf et al., 2018).

Coastal environment of Panvel has been under considerable stress since the ongoing construction of Navi-Mumbai International Airport (NMIA) by the City and Industrial Development Corporation (CIDCO). Construction of NMIA has resulted into deforestation, encroachment, reclamation and urbanization in the study area. It has affected the livelihood of local fishermen and coastal community along with ecology of fauna from Panvel, Navi Mumbai (Pawar et al., 2019 a, b).

Literature review suggests that barring few reports (Quadros, 2001; Nitsure, 2002; Verma et al., 2004; Pawar, 2011; Walmiki et al., 2013), meagre information is available on species diversity of birds from Panvel region. Hence the present study was undertaken to assess the impact of anthropogenic activities on species diversity and distribution of the birds from coastal region of Panvel, Navi Mumbai.

Although many studies have been undertaken to evaluate the species diversity of birds in India, no scientific studies have been carried out on the species composition and distribution of birds of Panvel, Navi Mumbai; hence, the present study is undertaken.

\section{Materials and Methods}

Study Area:

Navi Mumbai is basically a satellite township on the west shore of Maharashtra. It was made in 1971 to be another urban township of Mumbai by Government of Maharashtra. As per Census India 2011, it had a population of $1,119,477$. Panvel is located in Raigad district of Maharashtra in Konkan region and is a node of Navi Mumbai city. Geographically, Panvel is near Panvel creek which opens up in Thane creek. Kalundre river flows across the city in the south-west region and opens up into Panvel creek. Panvel with a population of 180,464 (Census India 2011) is a highly populated city due to its closeness to Mumbai. It is located in the Mumbai Metropolitan Region. Panvel is situated on the banks of Panvel Creek. It is also surrounded by mountains on 2 sides (Fig. 1).

\section{Study Location:}

The present study on diversity and distribution of avian species was carried out for the period of one year, from June 2019 to May 2020. Selected sites were visited during dawn and dusk hours, one day in each month and $4 \mathrm{~h}$ were spent at each site at both times (total day time was $8 \mathrm{~h}$ ).

The study sites were regularly surveyed by systematically walking on fixed routes and the bird population in different habitats was estimated by direct count (physical count and calls or voices) and indirect (nests, carcasses) observations. Data on birds was collected by observations with naked eyes and with the aid of 10 X 50 Olympus binocular. Birds were photographed using Cannon 1100 D Zoom camera. For correct identification of birds, field guides and books of Ali (2002) and Arlott (2015) were followed.

\section{Results and Discussion}

Varied diversity of birds with 102 species representing 16 orders, 48 families and 84 genera were observed (Figs. 2-5; Tables 1, 2). Number of species of birds distributed in each 


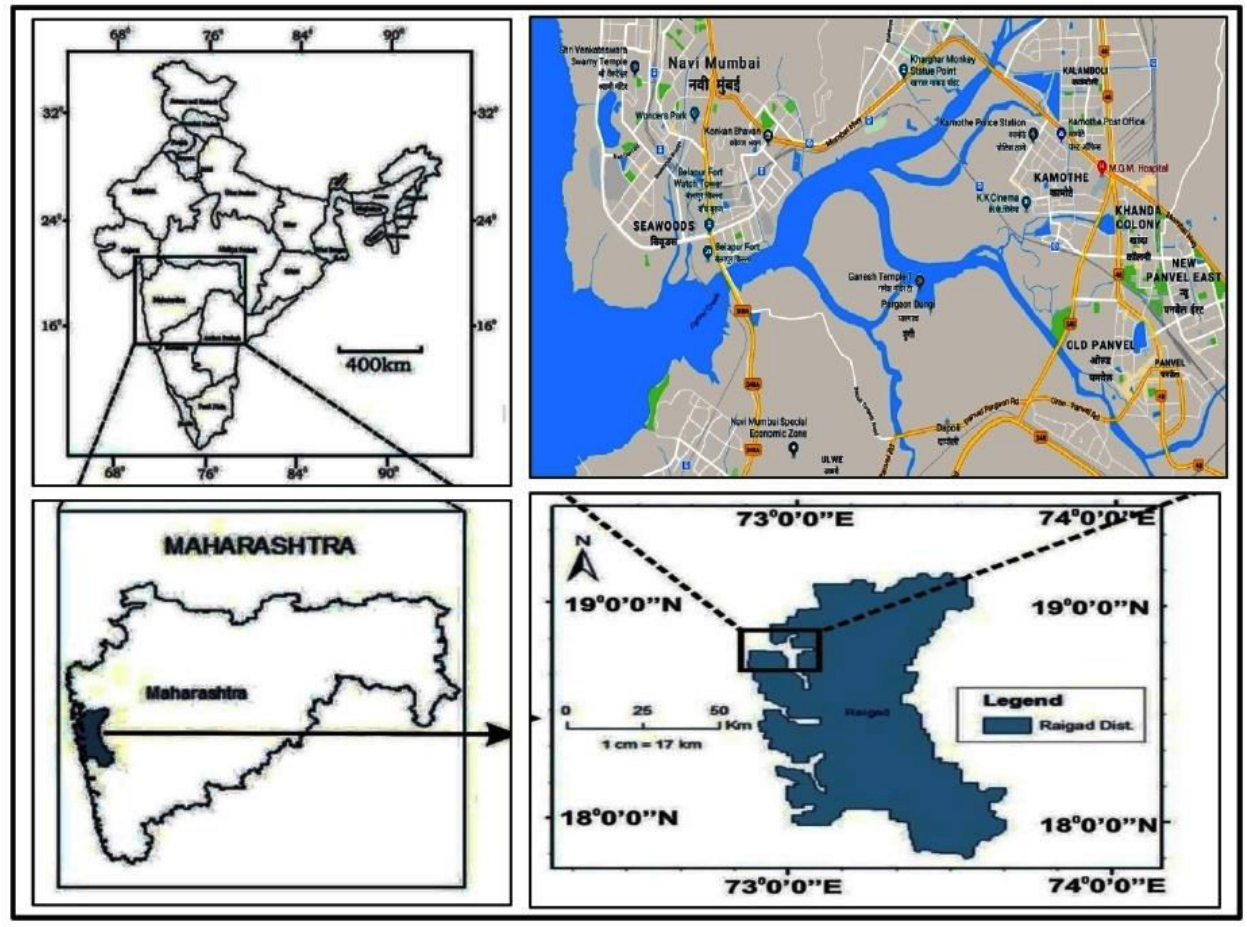

Fig. 1. Location map of study area representing Panvel creek.
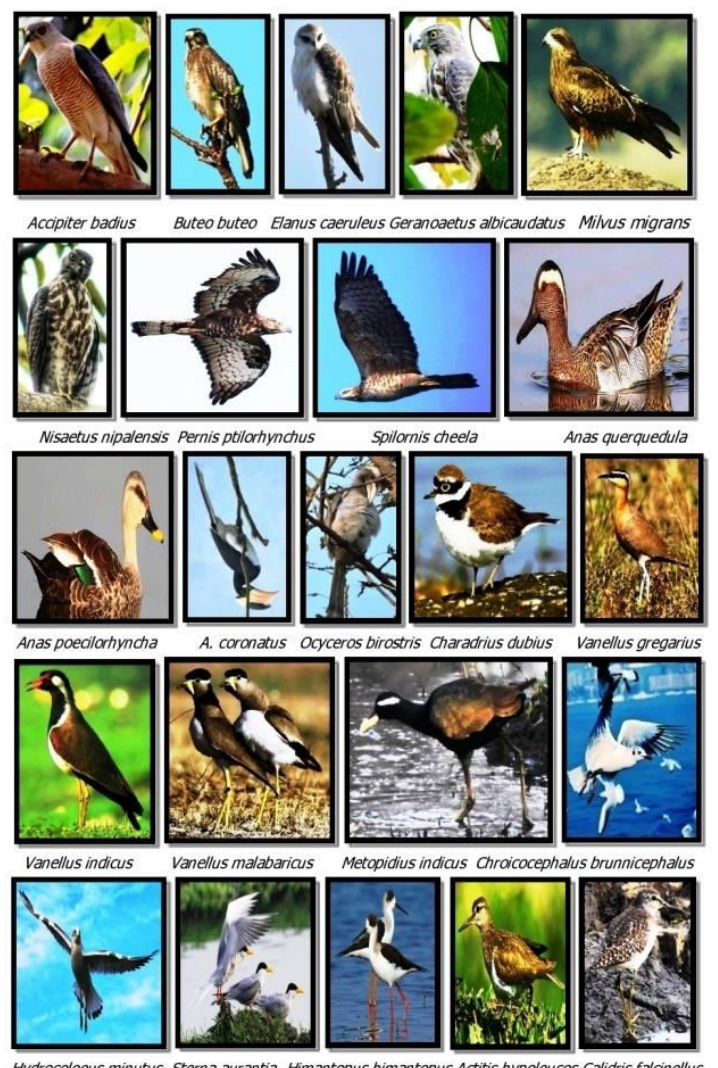

Hydrocoloeus minutus Sterna aurantia Himantopus himantopus Actitis hypoleucos Calidris falcinellus Fig. 2: Birds recorded in \& around Panvel, Navi Mumbai during June 2019 to May 2020
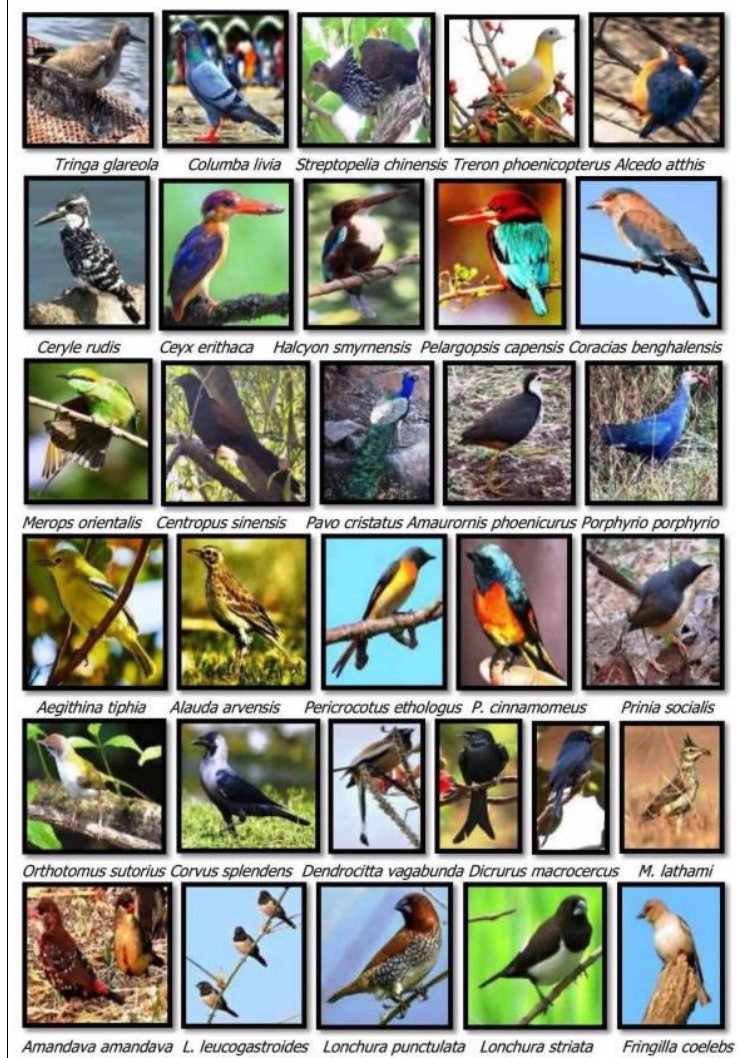

Fig. 3: Birds recorded in \& around Panvel, Navi Mumbai during June 2019 to May 2020 

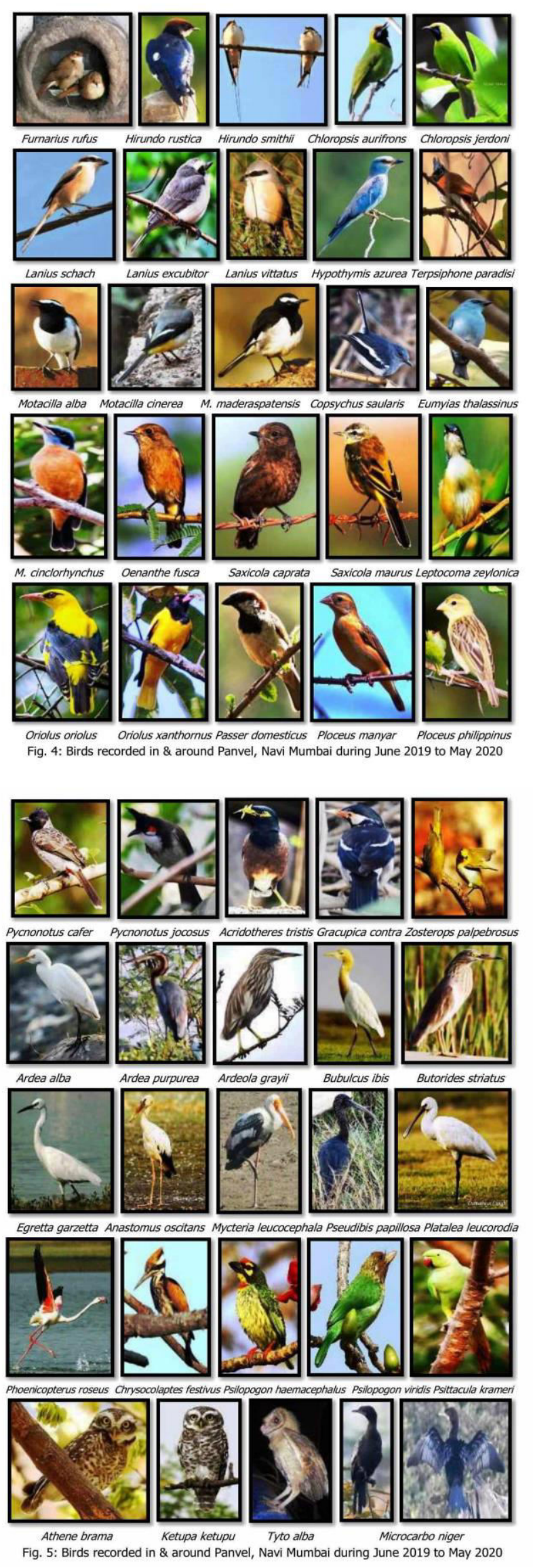

family reveals that 45 species belongs to family Passeriformes, 12 species to Charadriiformes, 10 species to Pelecaniformes, 8 species to Accipitriformes, 7 species to Coraciiformes, 3 species each to Columbiformes, Piciformes and Strigiformes; 2 species each to Anseriformes, Bucerotiformes and Gruiformes and 1 species each to Cuculiformes, Galliformes, Phoenicopteriformes, Psittaciformes and Suliformes (Table 2).

Altaf et al. (2018) documented that avian diversity and distribution in different habitats was impacted by factors like food, shelter, human presence, large fragmentation, loss of habitat, invasive plant species, and removal of plantation. Allen et al. (2019) reported that agriculture intensification produces negative impact on the bird diversity by use of chemicals, reduced nesting site, mortality of birds due to farming operations and increase in the predation rate after harvesting the crops. It is also noted that large area with high numbers of trees has positive relation with the bird diversity; the reason is that birds also can get food and shelter from the trees (Asefa et al., 2017; Allen et al., 2019; Maurice et al., 2020).

Pawar et al. (2019 a, b) correlated the depletion of coastal marine diversity from Panvel creek to the loss of habitat due to deforestation, overexploitation of natural resources for ongoing construction of NaviMumbai International Airport (NMIA), habitat fragmentation due to construction and widening of roads and rampant urbanization and industrialization of the area adjoining Panvel.

Results of the study are in agreement with the findings on anthropogenic impact on avian 
Table 1: Preliminary checklist of birds recorded in and around Panvel, Navi Mumbai

\begin{tabular}{|c|c|c|c|}
\hline Family & No. & Scientific Name & Common name \\
\hline \multicolumn{4}{|c|}{ Order - Accipitriformes } \\
\hline \multirow[t]{8}{*}{ Accipitridae } & 1 & Accipiter badius (J. F. Gmelin, 1788) & Indian Shikra \\
\hline & 2 & Buteo buteo (Linnaeus, 1758) & Common Buzzard \\
\hline & 3 & Elanus caeruleus (Desfontaines, 1789) & Black-winged Kite \\
\hline & 4 & Geranoaetus albicaudatus (Vieillot, 1816) & White-tailed Hawk \\
\hline & 5 & Milvus migrans (Boddaert, 1783) & Black Kite/Pariah Kite \\
\hline & 6 & Nisaetus nipalensis (Hodgson, 1836) & Mountain Hawk Eagle \\
\hline & 7 & Pernis ptilorhynchus (Temminck, 1821) & Oriental Honey Buzzard \\
\hline & 8 & Spilornis cheela (Latham, 1790) & Crested Serpent Eagle \\
\hline \multicolumn{4}{|c|}{ Order - Anseriformes } \\
\hline \multirow[t]{2}{*}{ Anatidae } & 9 & Anas querquedula (Linnaeus, 1758) & Garganey \\
\hline & 10 & Anas poecilorhyncha (J. R. Forster, 1781) & Spot-billed Duck \\
\hline \multicolumn{4}{|c|}{ Order - Bucerotiformes } \\
\hline \multirow[t]{2}{*}{ Bucerotidae } & 11 & Anthracoceros coronatus (Boddaert, 1783) & Malabar Pied Hornbill \\
\hline & 12 & Ocyceros birostris (Scopoli, 1786) & Indian Grey Hornbill \\
\hline \multicolumn{4}{|c|}{ Order - Charadriiformes } \\
\hline \multirow[t]{4}{*}{ Charadriidae } & 13 & Charadrius dubius (Scopoli, 1786) & Little Ringed Plover \\
\hline & 14 & Vanellus gregarius (Pallas, 1771) & Sociable Plover \\
\hline & 15 & Vanellus indicus (Boddaert, 1783) & Red-wattled Lapwing \\
\hline & 16 & Vanellus malabaricus (Boddaert, 1783) & Yellow-wattled Lapwing \\
\hline Jacanidae & 17 & Metopidius indicus (Latham, 1790) & Bronze-winged Jacana \\
\hline \multirow[t]{3}{*}{ Laridae } & 18 & Chroicocephalus brunnicephalus (Jerdon, 1840) & Brown-headed Gull \\
\hline & 19 & Hydrocoloeus minutus (Pallas, 1776) & Little Gull \\
\hline & 20 & Sterna aurantia (J. E. Gray, 1831) & River Tern \\
\hline Recurvirostridae & 21 & Himantopus himantopus (Linnaeus, 1758) & Black-winged Stilt \\
\hline \multirow[t]{3}{*}{ Scolopacidae } & 22 & Actitis hypoleucos (Linnaeus, 1758) & Common Sandpiper \\
\hline & 23 & Calidris falcinellus (Pontoppidan, 1763) & Broad-billed Sandpiper \\
\hline & 24 & Tringa glareola (Linnaeus, 1758) & Wood Sandpiper \\
\hline
\end{tabular}




\begin{tabular}{|c|c|c|c|}
\hline \multicolumn{4}{|c|}{ Order - Columbiformes } \\
\hline Columbidae & 25 & Columba livia (J.F. Gmelin, 1789) & Rock Pigeon/Rock Dove \\
\hline & 26 & Streptopelia chinensis (Scopoli, 1786) & Spotted Dove \\
\hline & 27 & Treron phoenicopterus (Latham, 1790) & Yellow-legged Green Pigeon \\
\hline \multicolumn{4}{|c|}{ Order - Coraciiformes } \\
\hline \multirow[t]{5}{*}{ Alcedinidae } & 28 & Alcedo atthis (Linnaeus, 1758) & Common Kingfisher \\
\hline & 29 & Ceryle rudis (Linnaeus, 1758) & Lesser Pied Kingfisher \\
\hline & 30 & Ceyx erithaca (Linnaeus, 1758) & Oriental Dwarf Kingfisher \\
\hline & 31 & Halcyon smyrnensis (Linnaeus, 1758) & White-throated Kingfisher \\
\hline & 32 & Pelargopsis capensis (Linnaeus, 1766) & Stork-billed Kingfisher \\
\hline Coraciidae & 33 & Coracias benghalensis (Linnaeus, 1758) & Indian Roller \\
\hline Meropidae & 34 & Merops orientalis (Latham, 1801) & Little Green Bee-eater \\
\hline \multicolumn{4}{|c|}{ Order - Cuculiformes } \\
\hline Cuculidae & 35 & Centropus sinensis (Stephens, 1815) & Greater Coucal \\
\hline \multicolumn{4}{|c|}{ Order - Galliformes } \\
\hline Phasianidae & 36 & Pavo cristatus (Linnaeus, 1758) & Indian Peafowl \\
\hline \multicolumn{4}{|c|}{ Order - Gruiformes } \\
\hline \multirow[t]{2}{*}{ Rallidae } & 37 & Amaurornis phoenicurus (Pennant, 1769) & White-breasted Waterhen \\
\hline & 38 & Porphyrio porphyrio (Linnaeus, 1758) & Purple Swamphen \\
\hline \multicolumn{4}{|c|}{ Order - Passeriformes } \\
\hline Aegithinidae & 39 & Aegithina tiphia (Linnaeus, 1758) & Common Iora \\
\hline Alaudidae & 40 & Alauda arvensis (Linnaeus, 1758) & Eurasian Skylark \\
\hline \multirow[t]{2}{*}{ Campephagidae } & 41 & Pericrocotus ethologus (Bangs and J. C. Phillips, 1914) & Long-tailed Minivet \\
\hline & 42 & Pericrocotus cinnamomeus (Linnaeus, 1766) & Small Minivet \\
\hline \multirow[t]{2}{*}{ Cisticolidae } & 43 & Prinia socialis (Sykes, 1832) & Ashy Prinia \\
\hline & 44 & Orthotomus sutorius (Pennant, 1769) & Common Tailorbird \\
\hline \multirow[t]{2}{*}{ Corvidae } & 45 & Corvus splendens (Vieillot, 1817) & House Crow \\
\hline & 46 & Dendrocitta vagabunda (Latham, 1790) & Rufous Treepie \\
\hline Dicruridae & 47 & Dicrurus macrocercus (Vieillot, 1817) & Black Drongo/King Crow \\
\hline Emberizidae & 48 & Melophus lathami (J. E. Gray, 1831) & Crested Bunting \\
\hline Estrildidae & 49 & Amandava amandava (Linnaeus, 1758) & Red Munia \\
\hline
\end{tabular}




\begin{tabular}{|c|c|c|c|}
\hline & 50 & Lonchura leucogastroides (Moore, F, 1858) & Javan Munia \\
\hline & 51 & Lonchura punctulata (Linnaeus, 1758) & Scaly-breasted Munia \\
\hline & 52 & Lonchura striata (Linnaeus, 1766) & White-rumped Munia \\
\hline Fringillidae & 53 & Fringilla coelebs (Linnaeus, 1758) & Common Chaffinch \\
\hline Furnariidae & 54 & Furnarius rufus (Gmelin, JF, 1788) & Rufous Hornero \\
\hline \multirow[t]{2}{*}{ Hirundinidae } & 55 & Hirundo rustica (Linnaeus, 1758) & Common Swallow \\
\hline & 56 & Hirundo smithii (Leach, 1818) & Wire tailed Swallow \\
\hline \multirow[t]{2}{*}{ Irenidae } & 57 & Chloropsis aurifrons (Temminck, 1829) & Golden-fronted Leafbird \\
\hline & 58 & Chloropsis jerdoni (Blyth, 1844) & Jerdon's Leafbird \\
\hline \multirow[t]{3}{*}{ Laniidae } & 59 & Lanius schach (Linnaeus, 1758) & Long-tailed Shrike \\
\hline & 60 & Lanius excubitor (Linnaeus, 1758) & Great Grey Shrike \\
\hline & 61 & Lanius vittatus (Valenciennes, 1826) & Bay-backed Shrike \\
\hline \multirow[t]{2}{*}{ Monarchidae } & 62 & Hypothymis azurea (Boddaert, 1783) & Black-naped Monarch \\
\hline & 63 & Terpsiphone paradisi (Linnaeus, 1758) & Indian Paradise-flycatcher \\
\hline \multirow[t]{3}{*}{ Motacillidae } & 64 & Motacilla alba (Linnaeus, 1758) & White Wagtail \\
\hline & 65 & Motacilla cinerea (Tunstall, 1771) & Grey Wagtail \\
\hline & 66 & Motacilla maderaspatensis (J. F. Gmelin, 1789) & White-browed Wagtail \\
\hline \multirow[t]{6}{*}{ Muscicapidae } & 67 & Copsychus saularis (Linnaeus, 1758) & Oriental Magpie-Robin \\
\hline & 68 & Eumyias thalassinus (Swainson, 1838) & Verditer Flycatcher \\
\hline & 69 & Monticola cinclorhynchus (Vigors, 1831) & Blue-capped Rock Thrush \\
\hline & 70 & Oenanthe fusca (Blyth, 1851) & Brown Rock Chat \\
\hline & 71 & Saxicola caprata (Linnaeus, 1766) & Pied Stonechat \\
\hline & 72 & Saxicola maurus (Pallas, 1773) & Siberian Stonechat \\
\hline Nectariniidae & 73 & Leptocoma zeylonica (Linnaeus, 1766) & Purple-rumped Sunbird \\
\hline \multirow[t]{2}{*}{ Oriolidae } & 74 & Oriolus oriolus (Linnaeus, 1758) & Eurasian Golden Oriole \\
\hline & 75 & Oriolus xanthornus (Linnaeus, 1758) & Black-hooded Oriole \\
\hline Passeridae & 76 & Passer domesticus (Linnaeus, 1758) & House Sparrow \\
\hline \multirow[t]{2}{*}{ Ploceidae } & 77 & Ploceus manyar (Horsfield, 1821) & Indian Streaked Weaver \\
\hline & 78 & Ploceus philippinus (Linnaeus, 1766) & Baya Weaver, Indian Baya \\
\hline \multirow[t]{2}{*}{ Pycnonotidae } & 79 & Pycnonotus cafer (Linnaeus, 1766) & Red-vented Bulbul \\
\hline & 80 & Pycnonotus jocosus (Linnaeus, 1758) & Red- whiskered Bulbul \\
\hline
\end{tabular}




\begin{tabular}{|c|c|c|c|}
\hline Sturnidae & 81 & Acridotheres tristis (Linnaeus, 1766) & Common Myna \\
\hline & 82 & Gracupica contra (Linnaeus, 1758) & Asian Pied Starling \\
\hline Zosteropidae & 83 & Zosterops palpebrosus (Temminck, 1824) & Oriental White-eye \\
\hline \multicolumn{4}{|c|}{ Order - Pelecaniformes } \\
\hline \multirow[t]{6}{*}{ Ardeidae } & 84 & Ardea alba (Linnaeus, 1758) & Great Egret/Large Egret \\
\hline & 85 & Ardea purpurea (Linnaeus, 1766) & Purple Heron \\
\hline & 86 & Ardeola grayii (Sykes, 1832) & Indian Pond-heron \\
\hline & 87 & Bubulcus ibis (Linnaeus, 1758) & Cattle Egret \\
\hline & 88 & Butorides striatus (Linnaeus, 1758) & Striated Heron \\
\hline & 89 & Egretta garzetta (Linnaeus, 1766) & Little Egret \\
\hline \multirow[t]{2}{*}{ Ciconiidae } & 90 & Anastomus oscitans (Boddaert, 1783) & Asian Openbill \\
\hline & 91 & Mycteria leucocephala (Pennant, 1769) & Painted Stork \\
\hline \multirow[t]{2}{*}{ Threskiornithidae } & 92 & Pseudibis papillosa (Temminck, 1824) & Red-naped Ibis \\
\hline & 93 & Platalea leucorodia (Linnaeus, 1758) & Eurasian Spoonbill \\
\hline \multicolumn{4}{|c|}{ Order - Phoenicopteriformes } \\
\hline Phoenicopteridae & 94 & Phoenicopterus roseus (Pallas, 1811) & Greater Flamingo \\
\hline \multicolumn{4}{|c|}{ Order - Piciformes } \\
\hline Picidae & 95 & Chrysocolaptes festivus (Boddaert, 1783) & White-naped Woodpecker \\
\hline \multirow[t]{2}{*}{ Ramphastidae } & 96 & Psilopogon haemacephalus (Statius Muller, 1776) & Coppersmith Barbet \\
\hline & 97 & Psilopogon viridis (Boddaert, 1783) & White-cheeked Barbet \\
\hline \multicolumn{4}{|c|}{ Order - Psittaciformes } \\
\hline Psittaculidae & 98 & Psittacula krameri (Scopoli, 1769) & Ring-necked Parakeet \\
\hline \multicolumn{4}{|c|}{ Order - Strigiformes } \\
\hline \multirow[t]{2}{*}{ Strigidae } & 99 & Athene brama (Temminck, 1821) & Spotted Owlet \\
\hline & 100 & Ketupa ketupu (Horsfield, 1821) & Buffy Fish Owl \\
\hline Tytonidae & 101 & Tyto alba (Scopoli, 1769) & Common Barn Owl \\
\hline \multicolumn{4}{|c|}{ Order - Suliformes } \\
\hline Phalacrocoracidae & 102 & Microcarbo niger (Vieillot, 1817) & Little Cormorant \\
\hline
\end{tabular}


Table 2: List of families with number of order, genera and species of birds recorded in and around Panvel, Navi Mumbai

\begin{tabular}{|c|c|c|c|c|c|}
\hline Sr. No. & Order & Family & Genera & Species & $\begin{array}{c}\text { Per cent } \\
\text { Representation }\end{array}$ \\
\hline 1 & Accipitriformes & 01 & 08 & 08 & 7.849 \\
\hline 2 & Anseriformes & 01 & 01 & 02 & 1.960 \\
\hline 3 & Bucerotiformes & 01 & 02 & 02 & 1.960 \\
\hline 4 & Charadriiformes & 05 & 10 & 12 & 11.765 \\
\hline 5 & Columbiformes & 01 & 03 & 03 & 2.941 \\
\hline 6 & Coraciiformes & 03 & 07 & 07 & 6.863 \\
\hline 7 & Cuculiformes & 01 & 01 & 01 & 0.980 \\
\hline 8 & Galliformes & 01 & 01 & 01 & 0.980 \\
\hline 9 & Gruiformes & 01 & 02 & 02 & 1.960 \\
\hline 10 & Passeriformes & 23 & 31 & 45 & 44.118 \\
\hline 11 & Pelecaniformes & 03 & 09 & 10 & 9.804 \\
\hline 12 & Phoenicopteriformes & 01 & 01 & 01 & 0.980 \\
\hline 13 & Piciformes & 02 & 03 & 03 & 2.941 \\
\hline 14 & Psittaciformes & 01 & 01 & 01 & 0.980 \\
\hline 15 & Strigiformes & 02 & 03 & 03 & 2.941 \\
\hline 16 & Suliformes & 01 & 01 & 01 & 0.980 \\
\hline Total & 16 & 48 & 84 & 102 & \\
\hline
\end{tabular}

diversity by Lepczyk et al. (2008), Debnath et al. (2018) and Katia et al. (2019). At present, ecological conditions in area adjoining Panvel, Navi Mumbai supports moderate density of birds but due to over-exploitation of natural resources for ongoing construction of Navi Mumbai International Airport, deforestation, intense industrialization and urbanization, coastal pollution will affect the avian diversity in future. Therefore, data presented in this paper can be taken as a base line data for future study.

\section{Conclusion}

The study shows that, at present, ecological conditions in area adjoining Panvel, Navi Mumbai supports moderate avian density. It can be concluded that over-exploitation of natural resources and deforestation in Panvel region due to ongoing construction of Navi 
Mumbai International Airport (NMIA) are the key factors affecting the diversity and distribution of avian species. As the bird community react rapidly to anthropogenic impact, restoration of large forest patches and well planned plantation of conservation plants is recommended. Since no earlier reports are available, data presented here can be taken as a baseline data in knowing the status of birds of Panvel, Navi Mumbai and effect of industrial development on it.

\section{Acknowledgement}

Encouragement and support provided by Dr. Ganesh A. Thakur, Principal, Mahatma Phule Arts, Science and Commerce College, Panvel, Raigad, Navi Mumbai is gratefully acknowledged. Authors are thankful to The Head, Department of Zoology for providing necessary facilities for the present study. Special thanks to Undergraduate Zoology students of department who worked as trained volunteers for this study.

\section{References}

Ali S. (2002) The Book of Indian Birds. Bombay Natural History Society, Oxford University Press. (Thirteenth Edition, Revised by J. C. Daniel), pp. 326. (ISBN 019566523-6).

Allen DC, HL Bateman, PS Warren, Albuquerque FS, Arnett-Romero S and Harding B. (2019) Long term effects of land-use change on bird communities depend on spatial scale and land-use type. Ecosphere 10: e02952. 10.1002/ecs2.2952.

Altaf Muhammad, Arshad J, Abdul MK, Khan MSH, Muhammad U and Zulfiqar A. (2018) Anthropogenic impact on the distribution of the birds in the tropical thorn forest, Punjab, Pakistan J. Asia-Pacific Biodiver. 11: 229 - 236. https://doi.org/10.1016/ j.japb.2018.03.001.

Arlott N. (2015) Birds of India (Pakistan, Nepal, Bhutan, Bangladesh and Srilanka). William Collins, An imprint of Harper Collins Publishers, 1 London Bridge Street, London SE1 9GF. pp. 621. E-book Edition, ISBN: 9780007560684.
Asefa A, Andrew BD, Andrew E McKechnie, Anouska AK and Berndt JR. (2017) Effects of anthropogenic disturbance on bird diversity in Ethiopian mountain forests. The Condor: Ornithological Appl. 119:416 430. doi: 10.1650/CONDOR-16-81.1.

Bhadouria BS, Mathur VB, Sivakumar K and Anoop KR. (2012) A survey of avifaunal diversity in wetlands around Keoladeo National Park, Bharatpur, Rajasthan, India. Bird Populations 11:1-6.

Debnath S, Souvik B and Panigrahi AK. (2018) Present status and diversity of avian fauna in Purbasthali bird sanctuary, West Bengal, India. Agric. Sci. Digest. D-4711: 1-8. DOI: 10.18805/ag.D-4711.

Dey A, Dipankar D, Sujitraj DC and Chaudhuri PS. (2013) A preliminary study on avifaunal species diversity of Maharaja Bir Bikram College Campus, Tripura, North East India. Internat. Multidiscipl. Res. J.. 3: 36-43.

Dwivedi U and Singh RK. (2017) Biodiversity of migratory birds in Khutaghat, Ratanpur Dist. Bilaspur (C.G.). World J. Pharm. Pharmaceut. Sci. 6: 1148-1155. doi: 10.20959/wjpps20177-9514.

Galgani F, Fleet D and Van Franeker J. (2010) Marine Strategy Framework directive-Task Group 10 Report marine litter do not cause harm to the coastal and marine environment. Official Publications of the European Communities.

Gatesire T, Nsabimana D, Nyiramana A, Seburanga JL and Mirville MO. (2014) Bird diversity and distribution in relation to urban landscape types in Northern Rwanda. The Scientific World Journal. Article ID 157824.. http://dx.doi.org/10.1155/ 2014/157824.

Joshi P and Vinod KK. (2014) Diversity of avifauna and effects of human activities on birds at Tawa Reservoir area of Hoshangabad district. Adv. Res. Agri. Vet. Sci. 1: 78-82.

Kadam SS and Dhar AS. (2017) Status and diversity of avian fauna in and around Bordi region, west coast of India. Int. Res. J. Biological Sci. 6: 15-18.

Katia L, Jose Fernando Villasenor-Gomez, Francisco Roberto Pineda-Huerta and Salgado-Ortiz J. (2019) Temperate forest bird communities associated with a historic mining impact area: do tailing remnant effects modify their structure? Revista Brasileira de Ornito. 27: 94 - 107.

Kurve PN. (2017) Habitat dependent avifaunal diversity along the coastline of Raigad district, (M.S.), India. Internat. J. Fauna Biol. Studies 4: 01-06.

Lepczyk C A, Curtis HF, Volker CR, Anna MP, Roger BH and Liu J. (2008) Human impacts on regional avian 
diversity and abundance. Conservation Biol. 22 :405 - 416. doi: 10.1111/j.1523-1739.2008.00881.x.

Maurice ME, Fuashi NA, Mbua RL, Mendzen NS, Okon OA and Ayamba NS. (2020) The environmental influence on the social activity of birds in Buea University Campus, Southwest Region, Cameroon. Interdiscipl. J. Environ. Sci. Edu. 16: e02210. https://doi.org/10.29333/ijese/6446.

Nitsure SR. (2002) Study of avifauna at Thane creek near Rituchakkra nature park. Master's thesis submitted to the Indian Institute of Ecology and environment. New Delhi. pp. 265.

Pawar PR. (2011) Species diversity of birds in Mangroves of Uran (Raigad), Navi Mumbai, Maharashtra, West coast of India. J. Exp. Sci. 2: 73-77.

Pawar Prabhakar R, Atul JP, Anil GR, Pawar NB and Shreya RP. (2019 a) Monitoring of anthropogenic threats to mangrove ecosystem of Panvel Creek, Navi Mumbai, India. Research Chron. 7: 74-84.

Pawar Prabhakar R, Meshram LN, Udawant SM and Rauphunnisa FI. (2019 b) Assessment of coastal pollution using faunal composition of macrobenthos from Panvel Creek, Navi Mumbai, West Coast of India. Research Chron. 7: 28-38.

Pedreros AM, Marilyn GU, Francisco EM and Heraldo VN. (2018) Effects of vegetation strata and human disturbance on bird diversity in green areas in a city in southern Chile. Avian Res. 9: 38. https://doi.org/10.1186/s40657-018-0130-9.
Quadros G. (2001) Study of inter-tidal fauna of Thane Creek. Ph. D. Thesis, University of Mumbai. pp. 293.

Rajashekara S and Venkatesha MG. (2015) Temporal and spatial avian community composition in urban landscapes of the Bengaluru region, India. J. Environ. Biol. 36:607-616.

Ratchford JS, Wittman SE, Jules ES, Ellison AM, Gotelli NJ and Sanders NJ. (2005) The effects of fire, local environment, and time on ant assemblages in fens and forests. Diversity Distribution 11: 487-497.

Sheta BM, Gamal MO, Mohamed AB, Mohamed ME and Lotfi ZH. (2011) Impact of some anthropogenic activities on the diversity of resident bird species at Damietta Region, Egypt. CATRINA. 6: 59 -74.

Verma A, Balachandran S, Chaturvedi $\mathrm{N}$ and Patil V. (2004) A preliminary report on the biodiversity of Mahul Creek, Mumbai, India with special reference to Avifauna. Zoo's Print J. 19: 1599-1605.

Walmiki N, Karangutkar S, Yengal P, Pillai R, Ajgaonkar P, Singh N and Sagre P. (2013) Avian diversity in and around Bassein Fort and Creek, district Thane, Maharashtra. Internat. J. Adv. Res. 1: 73-85.

Weeks BC, Nichar G and Shahid N. (2016) Bird assemblage vulnerability depends on the diversity and biogeographic histories of islands. PNAS. 113:10109-10114. www.pnas.org/cgi/doi/10.1073/ pnas.1603866113. 